Int. J. Dev. Biol. 56: 425-436 (2012)

doi: $10.1387 / \mathrm{ijdb} .123520 \mathrm{mr}$

\title{
The Trembley Effect or the birth of marine zoology
}

\author{
MARC J. RATCLIFF* \\ Faculty of Psychology and Educational Sciences, University of Geneva, Geneva, Switzerland
}

\begin{abstract}
At a time when Europe was engaged in the War of Austrian succession, an unknown scholar, Abraham Trembley, managed to dramatically influence the course of the Natural Sciences. He focused his interest not only on the properties of a new organism, the polyp later named Hydra, and its freshwater environment, but also on the communication of his discoveries to the most estimable scholarly circles of his time. Under the patronage of influential scholars, Réaumur in Paris and Folkes in London, he forged a new perspective on a common object - water. Everyone had seen a glass of water and through it he could project the concept of a wet laboratory and hence reshape the experimental practices of naturalists. His research propelled a surge of interest for investigation of the aquatic environment, a new line of investigative force that can be called the Trembley Effect. This effect pushed scholars to explore the shallow areas of water, to test the properties of tiny aquatic bodies, to examine the frontiers between organisms. Thanks to Trembley, it was the first time that, in a fully artificial setting, man could give life to an animal species, a practice that created for all of those who tried it, an enigmatic feeling of power that stirred passions for decades. Indeed this experimental approach that emerged in parallel to Linnaean classifications, inaugurated a new phase of Natural Sciences.
\end{abstract}

KEY WORDS: Abraham Trembley, History of natural sciences, Hydra, Marine zoology, Trembley Effect

\section{The slow naturalization of the sea}

\section{About mysteries of abysses}

Naturalization is a word used by historians and philosophers to define a very slow transformation of the representation of the world and of man from Antiquity to modern times. For instance, the naturalization of the soul transformed it from a divine essence to a set of competences embodied into the brain; the naturalization of the sky eliminated the traditional religious or symbolic interpretation (astrological symbols, or specific events related to a comet). Historians also speak of the disenchantment of the world that goes with the naturalization.

At the beginning of the eighteenth century, the sea was mostly known by what geographers, sailors, seamen, travellers and naturalists said about it. Since the Renaissance, cartographers had represented the known world as a unified geographic space, becoming more and more naturalized (Crone, 1966). But despite this slow process of naturalization, that disenchanted the world, the knowledge gap between the earth and the sea remained huge. It was not until 1725 that Count Luigi Ferdinando Marsili (1658-1730) published the first maps of marine depths in his Histoire physique de la mer [Physical History of the Sea], providing the foundation for a scientific field that would later become oceanography (Marsili and Boerhaave, 1725). Yet, although that first glance went below the surface, the bowels of the sea remained unreachable, and for good reason! Those who ventured there explored only shallow depths, looking for precious organisms as coral, pearls, purple, nacred mollusks, sea urchins, and beautiful shells (Fig. 1A) (Vedrenne, 2002).

Indeed deep water itself remained mysterious and books mostly represented its products. During the Renaissance, many engravings of aquatic organisms circulated in the folios of Pierre Gilles (1489-1555), Guillaume Rondelet (1507-1556), Ippolito Salviani (1514-1572), Conrad Gesner (1516-1565), Pierre Belon (15171564), Ferrante Imperato (1550-1625) and UlisseAldrovandi (15521605). Their texts were illustrated with fishes, mammals, serpents, amphibians, mollusks, crustaceans, corals as well as marine plants but in fact naturalists built their survey of the inhabitants of the sea by visits to the fish markets rather than on exploration of the depths. According to these books, the octopus (Fig. 1B) and the crab lived close to the mythic Hydra (Fig. 1C), to the marine satyr and to the fish-monk. Moreover many encyclopedists made use of the same wood engravings.

Like mountains, the inaccessible marine habitat evokes an imaginative world of unknown dangerous places, filled with violence and natural fury. The depths are scary places where one could

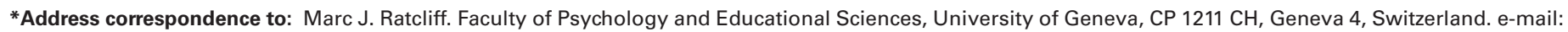
Marc.Ratcliff@unige.ch
} 

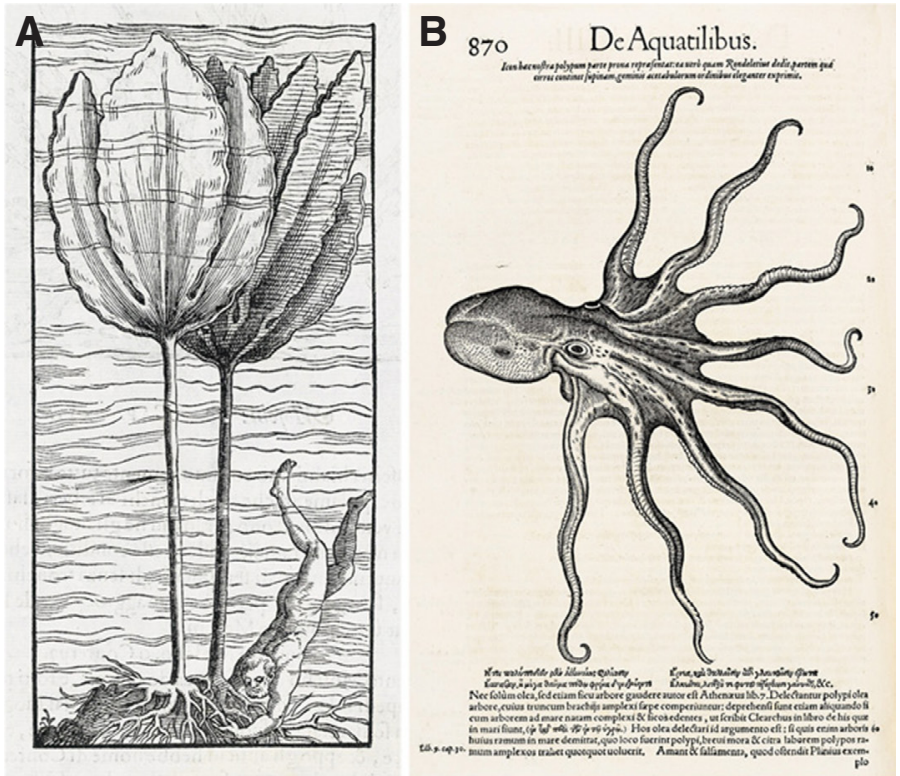

C

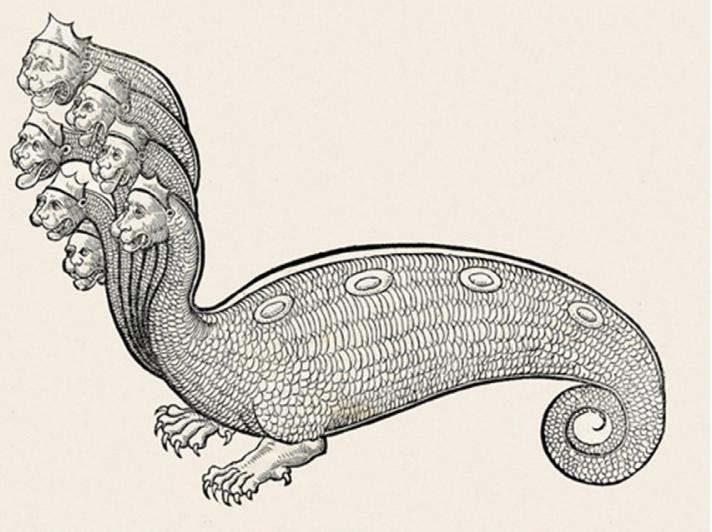

Fig. 1 (Left). XVIth century engravings of the sea and its marine productions. (A) Representation of a diver from Ferrante Imperato (1599). Dell'historia naturale libri XXVIII. In Napoli, per Costantino Vitale, p. 743. (B) An octopus, from Conrad Gesner (1558). Historia animalium liber IIII. Tiguri, apud Christoph Froschoverum, p. 870.(C) The mythic Hydra, from Gesner (1558), p. 543
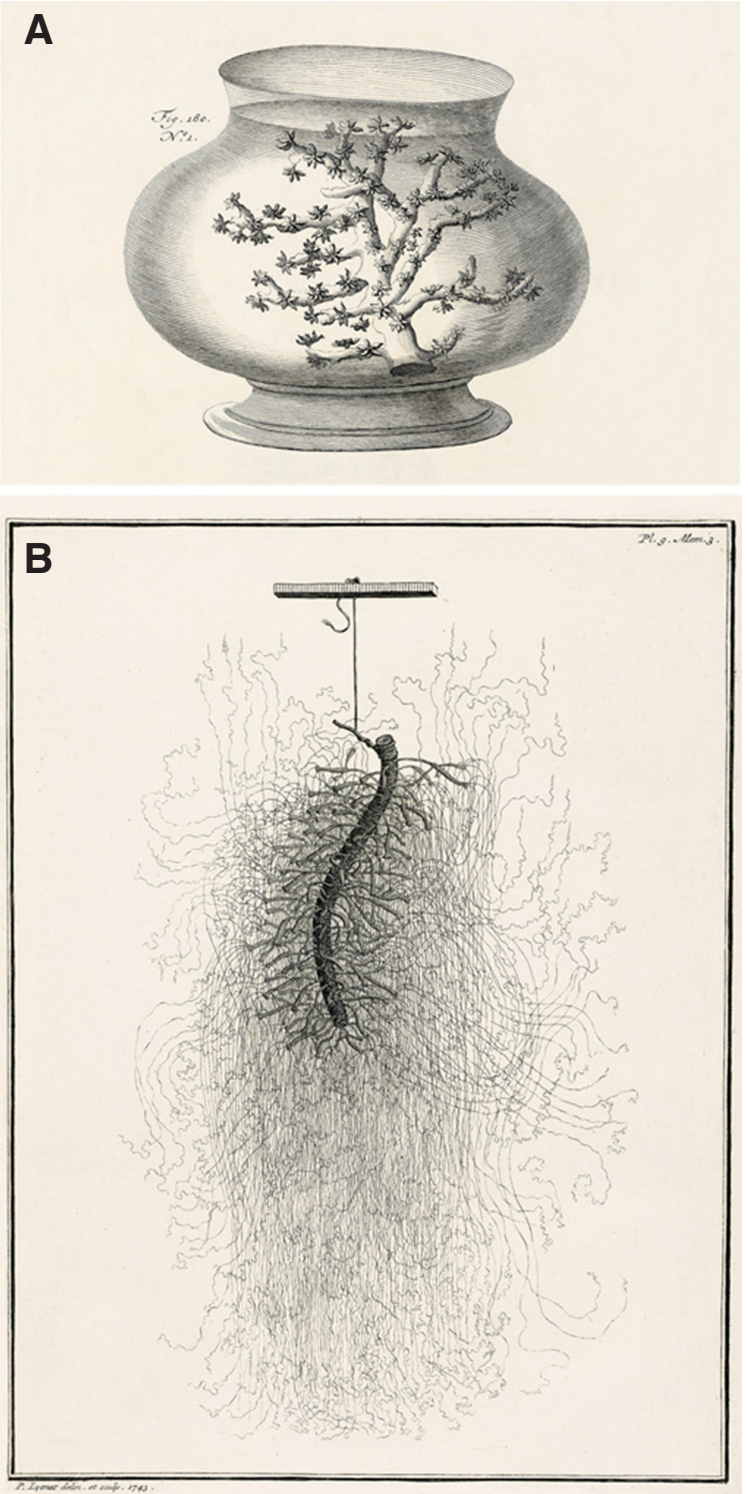

Fig. 2 (Right). Representations of coral and Hydra. (A) A coral 'branch' that spreads up when put in water, from Marsili and Boerhaave (1725), plate $X L$. (B) A colony of polyps engraved by Pierre Lyonet, from Trembley (1744), plate 9.

easily meet those Hydra, marine satyrs, water serpents and other monsters. The naturalists, among others, will become key players, to break these sterotypes and discover new scientific objects in the sea. Of the four sacred elements, water was the only one in which the insoluble inhabitants remained mysterious, except for those that were edible. In fact, Marsili categorized marine animals into two groups « edible and inedible ", introducing thus a simple economic motive to show that only the first category had been studied (Marsili and Boerhaave, 1725). By contrast, the history of the second group consisting largely of algae and «marine insects», - a generic name for the class of little bodies with legs - was neglected both by naturalists and seamen. The latter found no profit in bringing them to the cities, and so they threw them back into the sea; the scholars did not take the trouble to go fishing, and obviously did not acquire the knowledge necessary to build a new field. But things would soon change by the middle of the eighteenth century, «le Siècle des Lumières ».

\section{Simulating the sea}

In his preface to the Physical History of the Sea, the Dutch physician Herman Boerhaave (1668-1738) reiterated that the observation of a body needs to be done «on the spot of its birth, where it can be examined before it undergoes degeneration from its natural status» (Boerhaave, 1725). Acknowledging «an often insurmountable difficulty», he proposed that «to observe distant bodies, one first needs to get closer to them». However he could only note how the resistance of his peers to this new view delayed the fruitful progress that could be done in physics. Before observing the marine depths, scholars must at least go to the shore !

The Physical History of the Sea provided evidences about the 
empirical difficulties of field research, difficulties that scholars started to address. This was obvious in the assertion by Marsili (1707) claiming that coral was not a mineral, as many people believed, but a true plant (Marsili and Boerhaave, 1725). As a proof Marsili showed that when immersed in a glass jar filled with seawater, the flowers of coral came out of the branches (Fig. 2A). The discovery was well received first in the 1707 edition of Journal des Sçavants and restated in 1725. This little simulation of the vast water space would have profound consequences.

Between 1730 and 1760, other scholars improved the classification of marine organisms and characterized organisms living in water. In 1733 Johann-Heinrich Linck (1674-1734) described starfish; in 1738 Peter Artedi (1705-1735) proposed major keys for the classification of fish; Jacob Theodor Klein (1685-1759) classified sea urchins and Mathurin-Jacques Brisson (1723-1806) created the cetacea class in his Animal Reign(1756). But in contrast to the austerity of classification, the sea and its «creatures» still fascinated human beings, as shown by some representations of humanized marine creatures (Fig. 3).

When Marsili put corals in a glass jar filled with sea water, he invented a simple scientific procedure that artificially reproduced the aquatic environment. In 1738 Count of Ravenna Giuseppe Ginanni (1692-1753) started to experiment on the relationship of mollusks with water. To this end, he built a sort of miniaturized beach with a little woodbox filled with sand, put bivalves on it and poured in seawater. Nothing really was new here, as this was not very far from merchant's practices, although they did not use sand. However Ginnani transformed this artificial beach into an artificial shore by simulating the sea's motion, «several times per day for 15 minutes» (Ginanni, 1741). Furthermore he removed and added water to the box «to imitate the effects of the ebb and flow» of the sea. During several months of these artificial tide rhythms, he was able to establish the influence of water motion on the survival of the mollusks. Ginanni proved this phenomenon by using a control box, which was exactly the same but lacking any motion. In the control box the mollusks died after a few days, while they remained alive for several months in the moving box.

He first communicated his discovery to the Bologna Academy in March 1738, then he informed the Paris Academician RenéAntoine Ferchault de Réaumur (1683-1757). Réaumur (Fig. 4A) at that time in France (1730's) was one of the rare scholars who was well informed on this kind of scientific procedure. Coming from La Rochelle, a sea port, he had already worked on marine zoological issues (1710), on the regeneration of crustacea's legs, on algal reproduction and on the development of shells (Réaumur, 1709; Dinsmore, 1996). Hewas well disposed to understand this information and he was a major force in relaying this kind of naturalistic procedure, with no delay in dissemination of prodigious phenomena.

\section{A new world: Trembley's polyp}

\section{The discovery of polyps}

Born in Geneva in 1710, Abraham Trembley (1710-1784) (Fig. 4B) eluded the career of religious pastor planned by his father and got a PhD on mathematical infinity in 1730. At the age of 23 he emigrated to Holland to spare to his family «a mouth to feed». He registered at the University of Leyde in the mid-1730s and to earn his living he worked as a private tutor in the families of British noblemen. He got a position as tutor for the child of count William
Bentinck's (1704-1774) who soon became his patron(Baker, 1952).

Trembley was fond of experimental science and natural history (Buscaglia and Duboule, 2002; Galliot and Schmid, 2002). He had read Réaumur's Mémoires pour servir à l'histoire des insectes (Réaumur, 1734-1742) and in Leyde, he was hunting for insects that Réaumur described in his texts. In June 1740, while observing water insects in a pond, he discovered a strange and small mobile tube. He was in touch with other Genevan people, notably his nephew, Charles Bonnet (1720-1793), an enthusiast of the marvels of nature. Bonnet had already realized the impossible: in the summer 1737, at the age of seventeen, he dared to write to the master Réaumur and he started a scientific correspondance with him. Therefore Bonnet advised Trembley to do the same and the latter wrote to Réaumur in September 1740 to discuss entomology and to send him a few caterpillars.

Réaumur replied very positively. Now with confidence Trembley spoke of his little tubes adorned with little threads in December 1740. Intrigued by the precise description of this unknown aquatic body, Réaumur asked for a specimen in January 1741: «If you were to have enough of these little bodies (...) you could perhaps

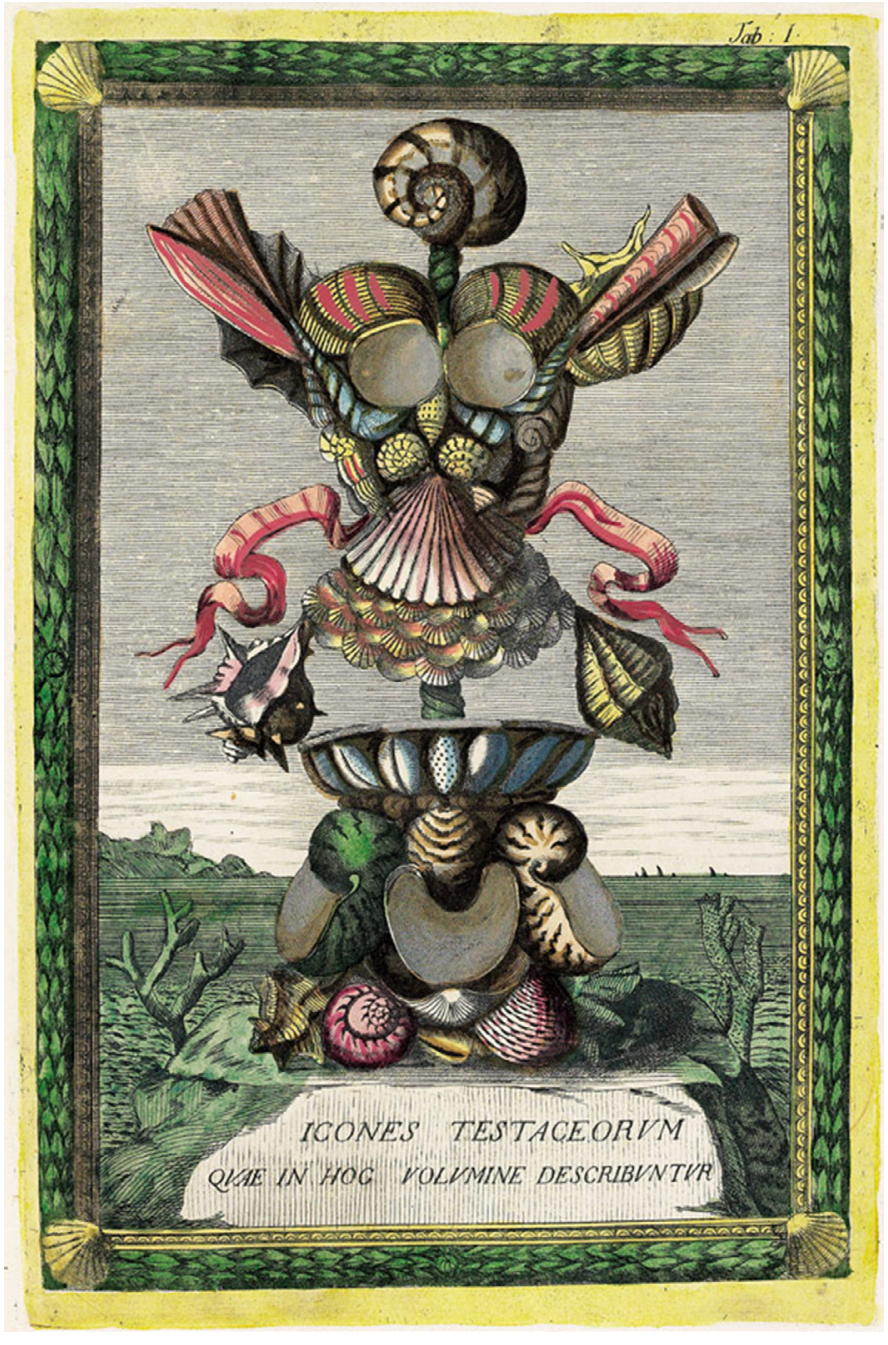

Fig. 3. Frontispiece of Athanasius Kircher's conchological cabinet, from Filippo Buonanni (1709). Musaeum Kircherianum. Romae, typis Georgii, p. 524. 
show them to me, by sending them in a small bottle filled with water, through the post » (Trembley and Guyénot, 1943). Trembley replied immediately and sent, on February 9th a little sealed vial filled with the mobile tubes. On February 27th, the mysterious bodies arrived dead in Réaumur's hands. To seal the vial, the academician suggested making use of cork instead of sealing wax, to allow the air to circulate. Encouraged by Réaumur, Trembley wrote longer letters and described his experiments on these bodies that behaved like animals but " which, being cut into several pieces, become so many perfect animals » (Gronovius, 1742). To make sure that the bodies would arrive safe and sound, Trembley experimented on the parcel, and tested the corked vial, travelling for a thirty kilometer ride. The experiment was successfull and the day after, he sent to Réaumur the vial, which arrived in Paris around March 20th 1741 (Fig. 2B).

A few days later, the whole Académie des sciences in Paris attended cutting experiments performed on the polyps. Once cut, the Hydra polyp regenerated into two bodies, even more actually, in as many bodies as there were cut parts. "Amazing! No one had ever seen animals reproducing with a method normally used to kill them » shouted Réaumur. The phenomenon was not only recognized but, moreover, everyone in Paris was speaking about it. Some scholars would not fail to see there a clear proof that the soul itself was divisible, a good point for the materialist ideas that were ready to emerge from obscurity at a time when French censorship forced many thinkers and philosophers to stay underground. The ideas linked to this discovery propagated to the whole Europe. For example, in England where the subtitle of a book written by the secretary of the Royal Society James Parsons (1705-1770) claimed to answer " some objections against the indivisibility of the soul, which have been inadvertently drawn from the late curious and useful experiments upon the polypus and other animals " (Parsons, 1752).

A

A

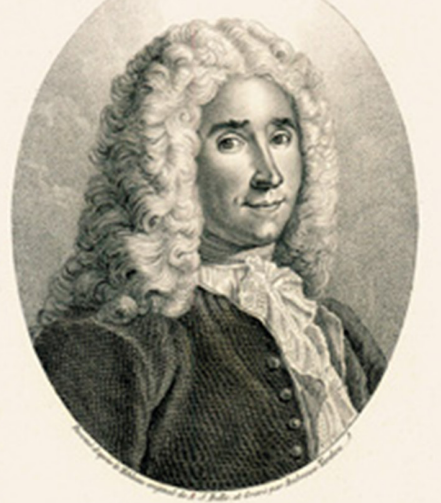

nExí. AxTOHXE VERCHAL LT DE R $\dot{X} \wedge \cup \geq \mathrm{U}$. (Zootogiste a Ilysiono Membre de Readémie des Seieners,

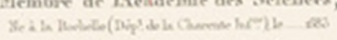

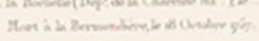

B

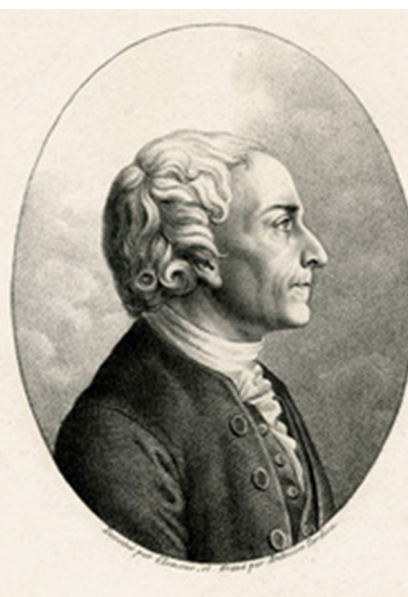

ABRAHAM TRBMBLXY (Philesophe et Zoologote). Correspondant de 1'Aendémio des Seirnees Merubre de la Soeintí royalo de Londres A:

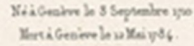

Plagiarized, awarded and published: Trembley's Mémoires

To understand the interest and the controversies about Hydra in the scholarly circles and the salons of the enlightened Europe, one can compare it to the debates about cloning during the 1990s. However in 1740, everyone could see the live polyp cut and selfreproducing, whereas the mysteries of cloning are kept secret behind the doors of high security laboratories. Actually one can reproduce the Hydra regeneration experiment in almost any place; one just needs some Hydra polyps and a pair of scissors. For instance, in June 1745 as Trembley was sailing on board William and Mary with Bentinck's' children, he met a physician who " had cut polyps and (...) tried to turn them inside out » (Trembley, 1745).

From 1740 on, Trembley continued to produce incredible phenomena in his office: from one cut polyp, he got fifty in three generations! He grafted half-polyp, he observed one polyp swallowed by another; he turned them inside out like the finger's of a glove. Going further than the myth, he managed to produce the famous Hydra with seven, even eight or nine heads! And always, the Hydra sprang up again, coming back to life after a few days. The life of these organisms seemed to rise up from Trembley's hands, coming out of his intricate manipulations and for the first time ever, life seemed to depend on man and not on God... As one may guess, such facts were both amazing and incredible, bringing the borders between fiction and rationality dangerously close. Trembley knew that he would have to convince both scholars and non-scholars alike as to the reality of these phenomena. Hence, he started very early to send polyps and detailed instructions to whoever asked for the animals to reproduce his experiments and from 1741 to 1744 Hydra polyps circulated in Europe.

This strategy of generosity gave rise to an odd episode: regeneration is probably the only discovery that was both plagiarized and honored before having been published, as well as pirated after its publication! In March 1743, the president of the Royal Society, Martin Folkes (1690-1754) received Hydra polyps from Trembley and distributed them among several fellows in order to have them reproduce the experiments. Among them, Henry Baker (1698-1774), fond of microscopy, read Trembley's letters to Folkes (Baker, 1743), and beginning in March 1743 he repeated all the experiments so carefully described by the Genevan scholar. Baker wrote his own journal of the experiments and published An Attempt towards a Natural History of the Polype in London in November 1743, thus stealing priority from Trembley and plagiarizing all his discoveries - although he cited him - on the pretext of reproducing the experiments. The behavior of the fellow was not really appreciated. Hence, at the end of November 1743, Folkes had the Copley Medal awarded to Trembley so that the honour of the society, responsible for that plagiarism, might be saved. In May 1744 Trembley published his Mémoires pour servir à l'histoire d'un genre de polypes d'eau douce à bras en forme de cornes in Leyde. The very successful book was pirated at the end of 1744 by the Paris

Fig. 4. (A) Portrait of René-Antoine Ferchault de Réaumur. (B) Portrait of Abraham Trembley. 
Publisher Laurent Durand (1712-1763) who published the French translation of Baker's Attempt (Fig. 5) (Trembley and Guyénot, 1943). Baker subsequently won the nickname of «philosopher in little things $» . .$.

\section{The Trembley Effect}

\section{Moving borders among organisms}

As a true heuristic object, regeneration generated a cascade of discoveries. In the 1720s, the flowers of coral were reconsidered by Jean-André Peyssonnel (1694-1759), a French physician close to Marsili. In 1723 he left the coral settled in sea water but, instead of the expected flowers, he observed small insects. He then wrote to Réaumur in 1726 to communicate his discovery, but the master was skeptical and wanted to judge for himself indeed the experiments had to be reproduced to gain full conviction. Réaumur could not travel to the south of France therefore men transported the coral in a glass jar, which arrived in Paris decomposed. The demonstration failed and as a consequence of the lack of understanding of the relationships between this marine organism and its environment, the coral remained a plant until Peyssonel contacted the Royal Society in London and convinced William Watson (1715-1787) of his major finding, corals are animals. William Watson translated and published Peyssonel's results in 1753 (Baker, 1743; Watson, 1753; Peyssonel, 1756; McConnell, 1990). Years later, Réaumur who had performed experiments on Hydra, recognized his error.

Indeed during the summer 1741, Réaumur was convinced by his own experiments performed on regenerating freshwater Hydra and by his correspondence with Trembley. He repeated the experiments before his colleagues, his nephew Brisson, the botanist Bernard de Jussieu (1699-1777) and the physician Jean-Antoine Guettard (1715-1786). Those experiments awakened in Jussieu's mind the image of an organism he had seen on the Atlantic shore. In September 1741, he travelled to the Normandy coast with the physician Noël-Sébastien Blot (1716-1758) to decide between two hypotheses: the « flowers » of coral might either be flowers or insects. Jussieu examined several species of coral-related species, most likely hydrozoan polyp colonies as Podocoryne or Hydractinia (Schuchert, 2008) and compared them to the Hydra model. The observations were irrevocable, the "flowers » were true animals, which were then named polypary (a colony of polyps) housing Hydra-like polyps. Jussieu reported the discovery to the Académie des sciences on November 24, 1742, proving the animal origin of " several of these marine plants, which he conserved in bottles » (Jussieu, 1742a).

When he put coral into bottles filled with sea water and conveyed them from the Atlantic coast to Paris, Jussieu actually made use of the same procedure as Marsili and improved upon by Réaumur and Trembley: «Whateverbe the substance to be examined in these organisms, either flower or animal, the plant that carried it might always be observed in sea water. We were careful in bringing glass jars, in which, filled with sea water, we could examine on

the place itself whatever plant we could find " (Jussieu, 1742b).

In spite of this methodological advance described in the Physical History of the Sea, the XVIII century scholars could not forget that the discovery of the "flowers » of coral hindered marine zoological research, a misinterpretation that prevented further developments now possible thanks to Marsili's innovation. In 1749, the French politician Chrétien-Guillaume de Lamoignon de Malesherbes (1721-1794), wrote « from 1727, no one spoke of coral and marine plants. (...) it was not until 1740 that Mr. Trembley, communicated his observations to the public, perhaps the most remarkable one of all naturalists» (Malesherbes, 1798). And it led to Jussieu's discovery: "Then people observed that many hypothetical marine plants on our coasts were actually polyparies

A MEMOIRES, L'H I S T O I R E D'UN GENRE DE

P O L Y P E S D'E A U D O U C E, A BRAS EN FORME DE CORNES:

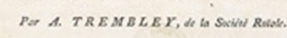

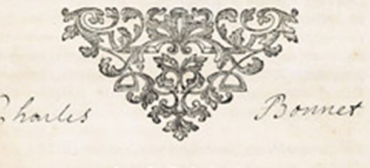

$\triangle \angle E I D E$,

CHERMAN VERBEEK,

M. DCC. $X L \perp V$

C An ATTEMPT towards a

Natural History OF THE P OL Y P E: In A LETTER To Martin Folkes, Efq;

PRESIDENT of the Royal Society. DESCRIBING

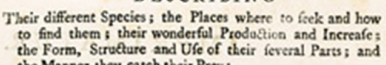

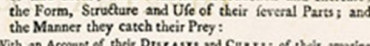

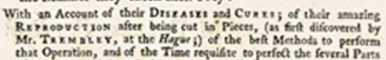

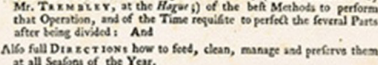

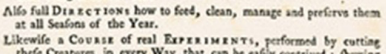

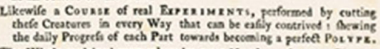

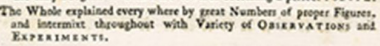

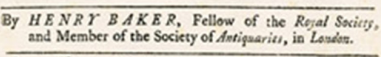

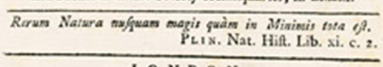
Prined for R. DO LOND O N:

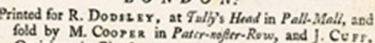

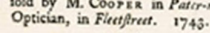
(Pfice booud Foar Shilling.)
B

$$
\begin{aligned}
& \text { M E M O I R E S } \\
& \text { poUR SERVIR } \\
& \text { A L'H I S T O I R E } \\
& \text { D'UNGENREDE } \\
& \text { P O L Y P S }
\end{aligned}
$$

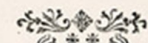

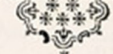

$$
\begin{aligned}
& \hbar
\end{aligned}
$$

D

$$
\begin{aligned}
& \text { E S S A I } \\
& \text { SUR L'HISTOIRE NATURELLE } \\
& \mathrm{D} U \\
& \text { P O L P E, } \\
& \text { I N S E C T E. } \\
& \text { Par M. Henry Baker, de la Sociét } \\
& \text { Royale de Londres, \& Membre de celle } \\
& \text { des Infcriptions. } \\
& \text { Traduit de l'Anglois } \\
& \text { Par M. P. Demours, Médecin de Paris. }
\end{aligned}
$$

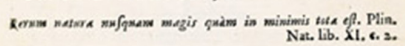

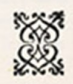

$$
\begin{aligned}
& \text { A PARIS, } \\
& \text { Chez D URAND, ruë Saint Jacques, } \\
& \text { M. D C C. X L I V. } \\
& \text { Avec Approbation of Privilégedu Roi. }
\end{aligned}
$$

Fig. 5. The books related to Hydra published in $\mathbf{1 7 4 3}$ and 1744. (A) Title page from Trembley (1744). (B) The French pirate edition of Trembley (1744) published by Durand in Paris. (C) Henry Baker (1743), a book that plagiarized Trembley's findings. (D) The French translation of Baker's book, also published by Durand in Paris in 1744. 
(...) we eventually rendered to Mr. Peyssonel the justice which he deserved ». Actually, an important change in the underlying conceptual framework took place, as attention was now focusing on the animal nature of the hypothetical « marine plants ». As a first evidence of the Trembley Effect, scholars started to look at aquatic beings with a different eye, being now convinced that the procedures implemented by A. Trembley for maintaining alive these organisms in an adapted environment played an essential role to establish the Hydra model. Some scholars drew the coral live immersed in sea water with small Hydra (a biological aberration as Hydra, a freshwater organism, cannot stand sea water). But those images presented a novel view of Natural History and if the Marsili glass jar was almost never represented, it was indeed because the procedure was now so routine.

\section{Water as life environment and field of investigation}

It is therefore in the changes in the understanding of the aquatic environment that one can identify a second aspect of the 'Trembley Effect'. In 1727, the failure of Peyssonnel demonstrated the difficulty of having aquatic organisms circulating efficiently. Trembley tackled similar issues when he sent polyps from Leyde to Paris then to London with the idea of having his experiments reproduced. Certainly, sending living organisms, from seeds to elephants, existed long before him. But, in 1741, sending Hydra was a new kind of parcel designed to specifically take into account

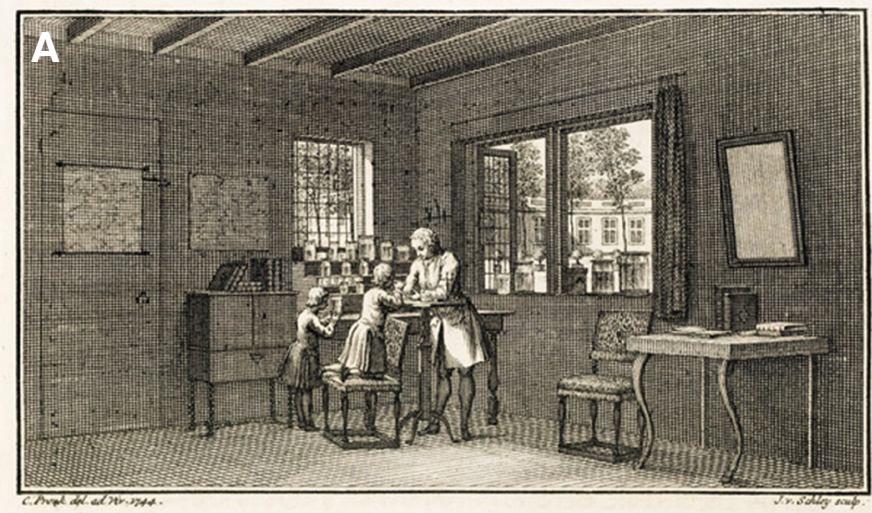

B

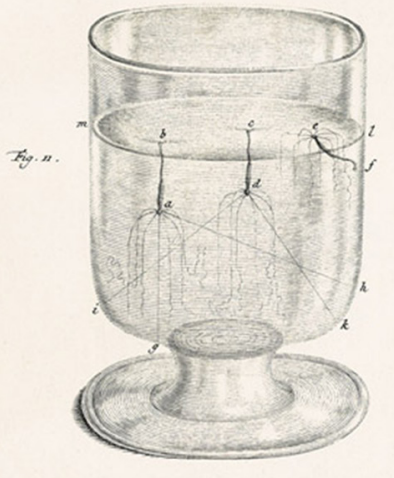

C

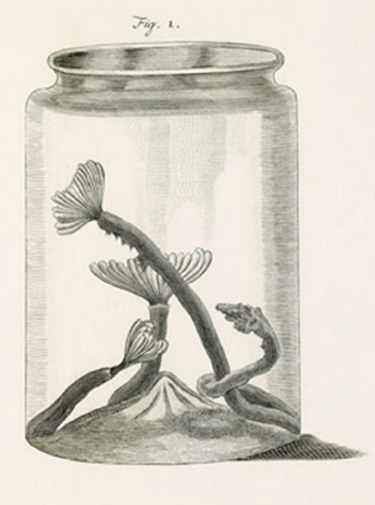

Fig. 6. Hydra in the laboratory. (A) Trembley and his pupils in his cabinet, from Trembley (1744). (B) Polyps in a glass, from Trembley (1744). (C) A glass jar containing a 'feather polyp' (Nereis lutaria), from Pierre-Simon Pallas (1778). Miscellanea Zoologica. Lugduni Batavorum, apud Sam. et Joan. Luchtmans, plate $X$. water, as the environment in which the organisms were living (Fig. 6B). Before Trembley, to send either a tiger or an insect one did not - transport the air around it. The only issues were food and putrefaction. But those were pre-trembley parcels. After Trembley, the notion of environmental milieugot a strong impetus, because scholars were now aware of working not only with an organism but with its environment as well. In today's words, it was a environment-organism-information system that circulated with Trembley's parcels (Ratcliff, 2004).

Such mailings required not only long preparation of the animals and their environment, but also it was necessary to send an abundance of organisms. Trembley developed the first laboratory cultures and a new stronger and deeper relationship to the room of observation that was transformed into a laboratory. He did not hesitate to display the model of his laboratory, to reveal his formula and much of his practical and tacit knowledge. In the vignette of the fourth part of his Mémoires, he staged himself, performing observations in his office with Bentinck's children. On the shelves and in front of the window, there are more than a dozen jars containing the polyps and their food (Fig. 6A). The example would make fortune: some offices were transformed into laboratories for the culture and conservation of aquatic bodies in their natural environment. However, although they were frequently cited, the jars were seldom represented as their use was becoming common for naturalists during the 1750s (Fig. 6C).

Trembley's research had a major impact on the representation of the aquatic milieu now considered as a framework for scientific discovery. The regeneration of the polyp had supplied scholars with a new scientific object and a new environment for study: the water. Therefore, indirectly but significantly, Trembley's effect would largely influence both microscopic research and marine zoology.

\section{The depths of the invisible}

Trembley's research oriented observations of scholars toward the aquatic organism to the detriment of other natural bodies. An insect, a worm or a caterpillar were easily enclosed in a box, and they live with virtually nothing: a stem, a leaf. This was the way the masters (Antonio Vallisneri (1661-1730), Réaumur and Johann Leonhard Frisch (1666-1743) had begun the study of entomology. To this end, from the 1670s, opticians and certain instrument-makers sold «flea glasses microscopes », small glass jars mounted on a wood or ivory base, with a lens to cover the box to allow for the observation of the insects enclosed within.

The size of Hydra is close to that of an insect, small enough to require, like them, the lens or the microscope, but big enough to be visible with the naked eye. This is a fundamental concept for who would believe that bodies invisible to the naked eye were real. Taking into accout the mean magnification of microscopes - between 10 and $80 x$ - insects showed the ideal size to serve as object-to-be-seen by the microscope. But the observation of insects with the microscope, although a scary experience, did not usually add something in itself, while observing Hydra that live in water, one moves necessarily to watch at their periphery. In other words, the observation of Hydra gave access to smaller animalcules that live around it in the same environment, and which are truly microscopic and invisible. Trembley was among the first ones to study them, and once his Mémoires were published in May 1744, he began eagerly to follow these tiny organisms that measured $0.1 \mathrm{~mm}$ and to better appreciate them, during the summer 1744 
TAB.LXVII

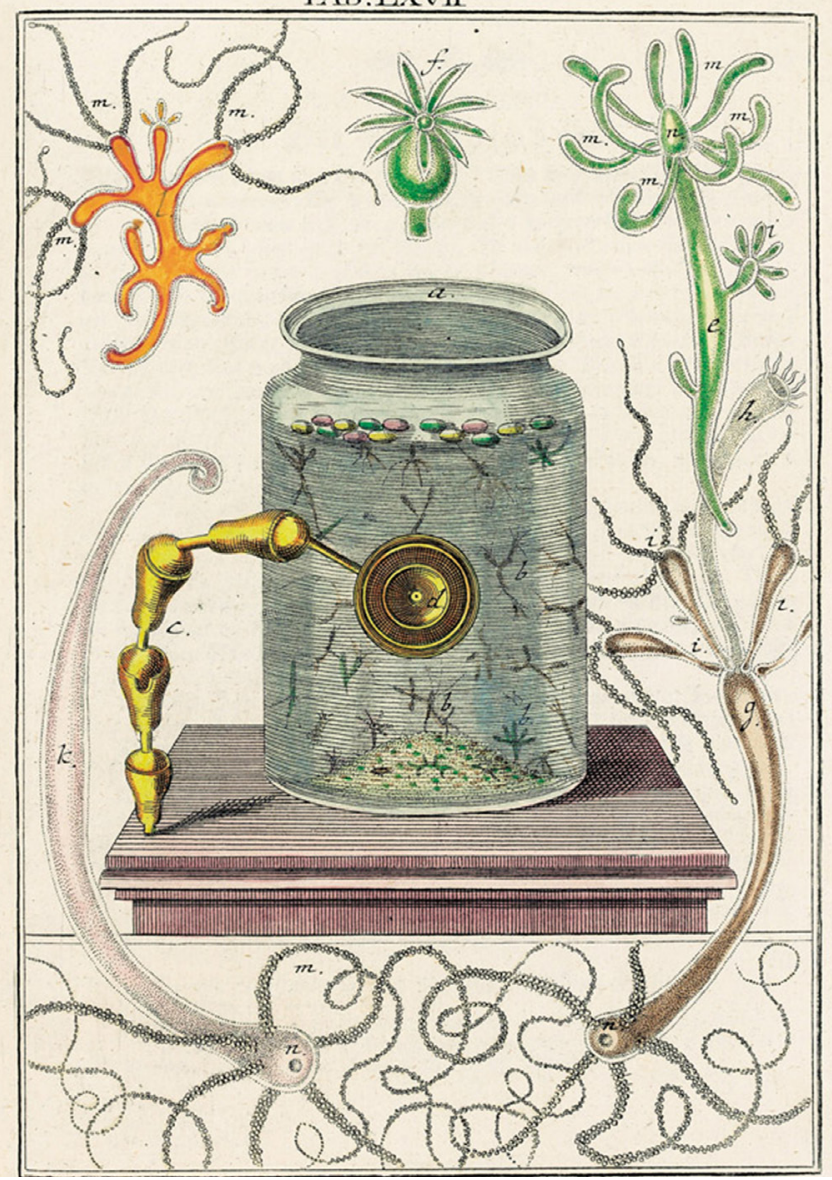

Fig. 7. Trembley's porte-loupe according to Martin Frobenius Ledermüller (1763). Mikroskopische Gemüths- und Augen-Ergötzung. Nürnberg, gedruckt von Christian de Launoy, plate LXVII.

he invented a porte-loupe for improving the observations (Fig. 7) (Ratcliff, 2006).

This is the third aspect of the Trembley Effect: the study of microscopic organisms at the periphery of Hydra's environment definitly broke the barrier between macroscopic and microscopic bodies. As a consequence the interest in invisible bodies grew rapidly in Europe in the 1740s and the frequency of scientific publications on microscopic bodies reached a peak in 1743, five times more than the mean number during the previous decade. In 1745 , the invention of the Leyde bottle attracted scientific attention (Heilbron, 1966), and in the following decades microscopic research continued to grow.

Because the polyp lived in an aquatic environment, it was never isolated and smaller bodies were always found around it, opening the doors to the infinite. This aspect of the Trembley Effect had already touched Réaumur and the Reaumurians in 1741, then England from 1743, then Italy and the German States. In March 1743, when Folkes received the polyps, it was the right moment to feed the hunger for microscopic research that had been rekindled a year before by Baker's Microscope Made Easy (Baker, 1742). In this context competition between scholars on the study of invisible bodies was stimulated. Along with Baker and John Turberville Needham (1713-1781), the peak of this research is seen in John Hill's (1714-1775) History of Animals (1752) that gave the first classification of «microscopical animalcules» (Fig. 8). However, his method would be superseded by the taxonomy of Linnaean authors (Linnaeus, 1758).

On the Continent, Trembley's effect influenced especially the German States, where certain authors who had studied « insects » looked into the polyp starting in the 1750s, and soon began research on microscopic bodies. The painter and naturalist Jakob Christian Schaeffer (1718-1790) from Ratisbon corresponded with Réaumur. He started his naturalistic career with the study of small crustacea (Schaeffer, 1752), then published the first original work on Hydra in German in which he classified many species of fresh water and marine "polyps » (Schaeffer, 1754; Schaeffer, 1755b ; 1755a ; Fryer, 2008). At that time, " polyp » was taken as a generic name that designated a vast number of species of little aquatic worms. The naturalist painter August Johann Rösel von Rosenhoef (1705-1759), from Nuremberg, followed a similar course. In 1746 he published a monthly entomological journal Der monatlich-herausgegebenen Insecten-Belustigung. After having depicted all kinds of insects according to the paradigm of natural theology - the naturalistic ideology that sang the marvels of the Creation - he dedicated in 1755 a full supplement to the polyp, with 210 pages and 28 illuminated plates (Rösel von Rosenhof 1755; Gierer 2012). Sometimes Hydra were even depicted with human caracteristics, like dancing (Fig. 9).

Bavaria was particularly prolific up to the 1760 s, because in Nuremberg, Martin Frobenius Ledermüller (1719-1769) published a periodical where he presented more or less everything which microscopic research had produced up to his time. Targeting a rich audience, the plates of his Mikroskopische Gemüths-und Augen-Ergötzung were engraved and illuminated. He illustrated other stylized polyps and also the Trembley's porte-loupe.

During the 1760s, while interest in the Hydra polyp was at its peak, scholars began to concentrate more directly on the study of microscopic organisms and the research became centered around several major networks: Bonnet's international network in Geneva, that of Lazzaro Spallanzani (1729-1799) in Pavia, those of Wilhelm Friedrich von Gleichen-Russworm (1717-1783) and Ledermüller in Bavaria, the future naturalistic Berlin society Berlinische Gesellschaft naturforschender Freunde launched in 1773, and that of Otto-Friedrich Müller (1730-1784) in Denmark. Several authors studied microscopic animalcules to experiment on their physiological properties. In 1765 Spallanzani published in Modena his Essay on microscopical observations that rekindled the controversy over spontaneous generation, showing that a microscopic species always produced offspring of the same species. In that context, in Geneva, and under the watchful eye of his uncle Bonnet, Horace-Bénédict de Saussure (1740-1799) discovered the fission of infusoria in 1765 . He presented there the first images ever drawn of a physiological process that would one century later be called mitosis.

From the 1770s, the microscopic research was developed enough to become a new branch of natural history. Using the Linnaean keys and nomenclature, Müller classified 150 invisible species in his 1773 Vermium terrestrium et fluviatilium historia, a work that founded the modern systematics of infusoria. Microscopic research had by then reached a point of no return, and scientists would not stop listing new species. In his posthumous Animalcula 
infusoria (1786) Müller already had 380 species described and drawn, sometimes with amazing shapes.

\section{Marine zoology, a European scholarly enterprise}

\section{From the interest in regeneration to marine zoology}

The fascination of the mysterious process of regeneration soon caused multiple research on what people called the " reproduction » of animals. The regeneration of the lizard's tail, and the legs of crustacea were known since Antiquity. In 1712 Réaumur experimented on the Vendean coast to test whether or not crabs could rebuild a cut leg (Réaumur, 1714). Since Hydra were not so easy to find, many people would start to cut all the bodies found

\section{ANIMALCULES}

GYMNIA
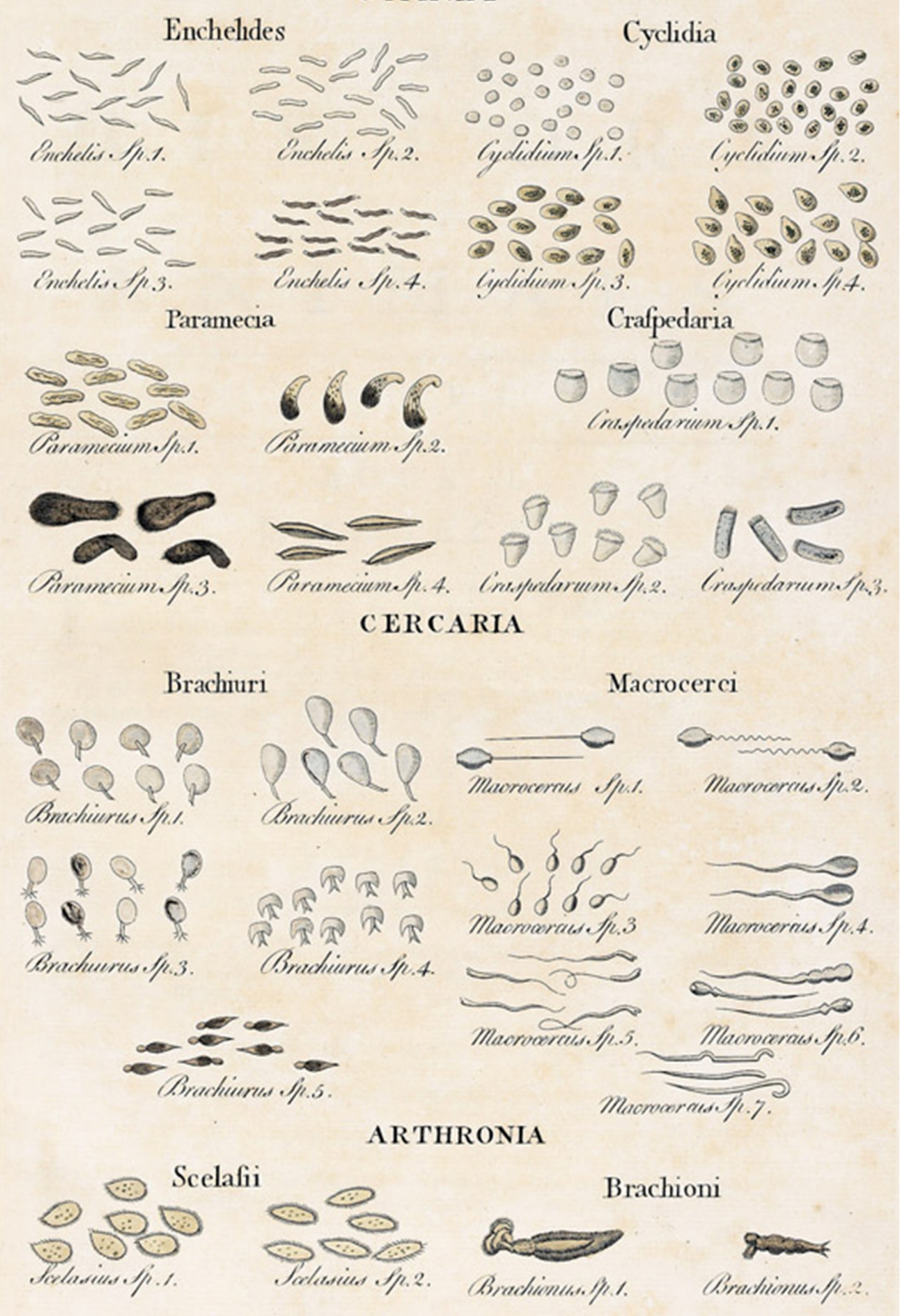

Fig. 8. The first attempt of classifying microscopical organisms, by John Hill (1748-1752). A General Natural History. London, Osborne, 3 vols. vol. 3: History of Animals, plate 1 . on the bank of a river, on the shores of seas, lakes and ponds. It is impossible to estimate the number of aquatic specimens that were mutilated during the decade 1740 for the sake of seeing regeneration. For instance, the astronomer Charles-Marie de La Condamine (1701-1774) heard the news of regeneration in June 1744 when he was in South America. He started to cut « big polypuses that were very common on that coast »(La Condamine, 1745), probably octopus, to see if their limbs regenerated. In Geneva, Bonnet did not find polyps and therefore cut little fresh water worms in which he observed the full regeneration in two months (Dawson, 1991).

On the other side of the Channel, in the network of the Royal Society, the fellows quickly experimented on the polyps, thanks to the information and stock/strains sent by Trembley. So much so that in Spring 1743 a full issue of the Philosophical Transactions was dedicated to a single subject: the polyp - which had never been the case before. After that, new naturalistic vocations would soon be born, and many amateurs and scholars started to scrutinize the coasts and shores of England, looking for marine animals likely to regenerate. Needham studied the regeneration of the starfish and described the sexual organs of the cuttlefish (Needham, 1747). Baker was the head of a network of amateur naturalists, while Hill and the naturalist and apothecary John Ellis (1714-1776) described and classified marine bodies. Ellis' Essay towards a Natural History of the Corallines (1755) developed Jussieu's thesis that the coral was a polypary, and established a new classification of corallines.

\section{Vertical procedures: the marine expedition}

Microscopists had made use of the Trembley parcels, and now that water was a new field for research, the naturalists would soon develop methods for the exploration of the sea. In 1725, Marsili had launched the marine expedition, a methodological foundation for future marine zoology. He measured the temperature, the type of water, the height of tides and the deepness of the sea bed on the coasts of Provence (Marsili and Boerhaave, 1725). Aboard seamen's boats, he hunted for marine plants, but mainly sought to study marine physics. He employed several instruments, like the thermometer, the aerometer, the scale, the height gauge, the microscope, the retort and chemical instruments. The techniques for collecting specimens came from the coral fishermen, who made use of their traditional tool, the St. Andrew's Cross and the landing net.

The Physical History of the Sea described many « marine plants », but apart from the flowers of coral, no natural history theory stemmed from Marsili's research, for whom the history of the sea was a part of the earth's history - in other words, geology. Twenty years later, things had changed. To have acccess to the sea bed, in his Marine Natural History of the Adriatic (1750), the Turin naturalist Vitaliano Donati (1717-1762) described instruments specifically invented for collecting marine bodies - water pincers, a sounding line with fish hooks and a winch (Donati, 1750). He also gave details on the preparation of the marine expedition.

Many authors followed the trend and started to venture out on marine field trips. In England, Ellis became a specialist in the study of aquatic organisms. The frontispiece of 
his Essay gathered both vertical and horizontal dimensions. On a fictious shore lay rising marine plants, which one could actually see only on the sea bed, while offshore two ships and a row boat are on a marine expedition. Not only water but also the sea bed were naturalized here, contrasting with Marsili's images. In the frontispiece of the Physical History of the Sea, the mythological Neptune was sitting on a shell while many marine species - fishes, crustacea, mollusks, corals - seemed more stranded than alive in a view that represented the marine bed. Such illustrations also reveals the difficulty of artists to envision the depths of the sea, a scene no one had seen.

With Trembley, Jussieu and Donati, a new world was revealed and the marine expedition became a major method for hunting marine bodies. In 1752, Hill was amazed by the amount of natural bodies which he collected in only one trip, around 60 marine animals and 112 plants (Hill, 1752). Significantly, he now « knew where to go for them again ", an essential component of research on marine species. This was the first step for geographers studying marine soils to identify reserves.

Usually, scholars collected organisms on the coasts and published in the cities, as did Marsili, Réaumur, Artedi, Klein, Jussieu, Donati, and the generation of naturalists of the second half of the century that included Peter-Simon Pallas (1741-1811), Ellis, Hill, Brisson, Jacques-François Dicquemare (1733-1789) and Filippo Cavolini (1756-1810). But despite the new procedures, the conservation of living organisms remained very difficult, as Hill remarked: "in the numbers that occurred in this research, and had been brought up to town in safety, more than one or two have furnished matter for these essays. The far greater part perished by degrees, almost unobserved, during the examination of the others » (Hill, 1752).

For their preservation, scholars simply utilized Marsili's jars filled with seawater (Donati, 1758), but the technique of moving water invented by Ginanni would not be generalized until the twentieth century. One thinks of the Chinese redfish that do not need water motion. They were so common in Europe during the Enlightenment that F. N. Martinet's described a hundred varieties in his Natural History of Chinese Dorads (1780). « Everyone has seen the little gold fishes from China » wrote Jean-Élie Bertrand (Bertrand, 1776) and up to the Revolution, the fashion had not changed as noted by Pierre-Joseph Bonnaterre: « the small red fishes from China, nowadays so common among us» (Bonnaterre, 1788). But the jar was far from the modern aquarium - an invention of the midnineteenth century -, rather regular Chinese jar.

At the same time, certain scholars systematically described fishing techniques. From 1769 to 1782, the French academician and marine inspector Henri-Louis Duhamel du Monceau (1700-1782) published three in-folio volumes of his Fishing Treatise where he described in well-documented plates everything that regards fishes from the economic viewpoint: practices and vocabulary of fishermen of the world, boats, tools, nets, species, etc. (Duhamel du Monceau and La Marre, 1769). But fishermen do not necessarily have motivation for collaborating with scholars. In 1770, the French physician Antoine Gouan (1733-1821) complained in his History of fishes: "We would be very obliged towards inhabitants of the sea coasts who would meticulously gather everything that come from the sea, and who convince the fishermen to never reject anything before it had been examined " (Gouan, 1770).

\section{Natural variety and biodiversity}

In his Natural History, Pliny the Elder had already noticed that " all living beings born in a given place within nature can also be found in the sea, plus many others that exist only in the sea " (Saint-Denis, 1955). But it was only in the 1740s that this idea met the needs of scientific research. In December 1741, Réaumur wrote to Trembley a sentence that illustrated well the recent advances and the new ideas that came from the observers grappling with the aquatic environment: "The class of polyps (..) is much more all encompassing than we had imagined 》 (Trembley and Guyénot, 1943). Not only water had been domesticated, but the representation of nature was clearly changing. Thanks to the observation of aquatic environment, the observers begun to understand how to deal with these abundant water organisms. Indeed Réaumur was aware of this large number of marine species and fully conscious of its potential, a kind of huge and protected reservoir, opening a vast horizon of research where the microscopic would meet the aquatic world. The polyp was regarded as a prototype for research and its natural properties challenged the scholar's ideas. In November 1742, Réaumur confessed to Bonnet: «This class of insects [polyps] is one of the larger classes of species, and it is perhaps the strangest, given the peculiarities it embodies " (Trembley and Guyénot, 1943).

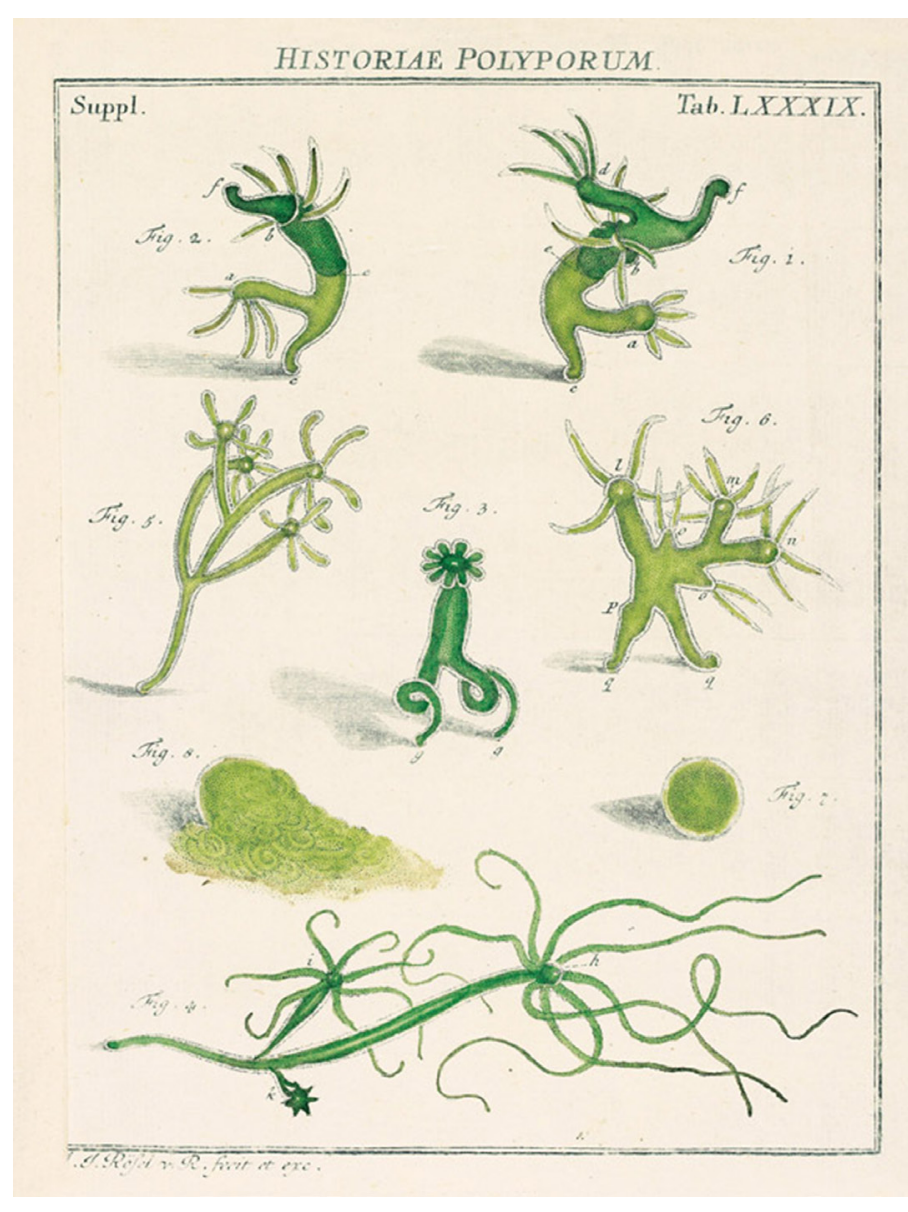

Fig. 9. Polyps dancing, from August Johann Rösel von Rosenhof (1755). Die Historie der Polypen der süssen Wasser. Der monatlich-herausgegebenen Insecten-Belustigung 3: 433-624, plate LXXXIX. 
Such a quotation perfectly reflects the enlightenment of naturalists facing the marine environment. Coming from the deep sea, the concepts of variety and multiplicity of species and the origin of the idea of biodiversity became fundamental issues in the study of nature. For example, Donati was interested in the sea not only from a geophysical viewpoint - he described the variation in height of marine soils -, but also from a « biological » point of view, as a first step for discovering new organisms and natural laws: «This element is the most populated of all; It seems to me that Nature shows there laws more numerous and diversified, for the conservation and multiplication of such a huge amount of beings (...) Thus there are many discoveries to do in that Reign 》 (Donati, 1758). This passage got Trembley's attention in his 1756 review of Donati's book: "The sea contains a prodigious number of organized bodies.. extremely different, in many respects, from the plants and animals of the earth; and which, for that reason, must necessarily discover to us new laws in nature ".

Donati also described several species of coral that « give a right idea of that kind of uniformity joined to variety which we admire in the laws of Nature » (Donati, 1758). Coming then both from the core and the periphery of Trembley's research, there were many changes that influenced the scientific field of marine zoology: naturalization of water, circulation of aquatic organisms, microscopic research, zoological experimentation, awareness of the variety of live organisms, etc.. The interest in natural history, related to the increase of scholarly travel, would cast upon Europe, thousands of new organisms to study and classify.

\section{A flood of marine organisms, networks of scholars}

From the 1740s onwards, the interest for marine zoology was growing in many European countries. England was influenced by Baker, Needham, Hill and Ellis. From the time of Hans Sloane (1660-1753), scholars and painters had begun to describe the natural history of the colonial countries in books that also described zoophytes, such as those by Mark Catesby (1683-1749) and George Edwards (1694-1773). The trend lasted with James Cook's (17281779) travels in which naturalists took part, while other authors cultivated conchology as Emanuel Mendes da Costa (1717-1791), William Boys (1735-1803) and George Walker, Georges Shaw (1751-1813). In Holland, after Job Baster (1711-1775), several authors studied marine zoology, microscopic or not, like Pallas and Martinus Slabber (1740-1835). From the 1750s, scholars started to describe and classify marine species thanks to the Linnaean nomenclature, which they introduced in the Dutch iconographical tradition represented by Slabber who drew microscopic aquatic organisms.

In France, the study of shells by Antoine-Joseph Dezallier d'Argenville (1680-1765), Étienne-Louis Geoffroy (1725-1810), Michel Adanson (1727-1806), Jean-Guillaume Bruguière (1750-1798) and fishes by Brisson, Duhamel, Jean-Louis de la Marre, Gouan, Francois-Nicolas Martinet (1731-1800), Pierre-Marie Broussonet (1761-1807), Pierre-Joseph Bonnaterre (1752-1804), Bernard de Lacépède (1756-1825) clearly developed marine zoology. Fish studies were improved with Jean-François Durande (1732-1794), Dicquemare and Guettard. At the time of the Empire, the studies multiplied very quickly and the use of new classifications related to Antoine-Laurent Jussieu's (1748-1836) natural method turned several scholars to working on aquatic organisms as François-Marie Daudin (1774-1804), Louis-Augustin Bosc d'Antic (1759-1828),
Georges Cuvier (1769-1832), Jean-Baptiste Lamarck (1744-1829), Jean Lamouroux (1779-1825), Jean-Baptiste Bory de Saint-Vincent (1778-1846).

Italy is one of the European countries with the longest coast length in proportion to its surface. At the middle of the XVIII ${ }^{\text {th }}$ century, marine zoology spread much with the works of Ginanni, Gualtieri, Plancus and Donati. In the south of Venice, in Chioggia, a brillant naturalistic school developed: Giuseppe Vianelli (1720-1803) determined the causes of marine phosphorescence in 1749 with his description of the noctiluca (Vianelli, 1749; Lazzari, 2006). From the 1770s, more than a dozen authors took up marine zoology, and explored the privileged environment of Venice's gulf: Spallanzani, then the Linnaeans Ambrogio Soldani (1733-1808), Stefano-Andrea Renier (1759-1830) et Giuseppe Olivi (1769-1795) described its marine bodies. However, some important works remained unfinished or unpublished, like the six volumes of Spallanzani's History of the sea, or Renier's works. Abbott Olivi who wrote a good history of Adriatic sea, died at the age ot 25. The gulf of Naple also attracted travellers like Johann-Baptist Bohadsch (1724-1772) and Needham who performed observations there (Bohadsch, 1761), before Cavolini's works that founded marine zoology in the south of Italy during the 1780s (Cavolini, 1785).

In the German states, conchology was deeply cultivated by CarlAugust Bergen (1704-1750), Georg-Wilhelm Steller (1709-1746), Friedrich-Heinrich-Wilhelm Martini (1729-1778), Christian-Friedrich Schulze (1730-1775), Johann-Samuel Schroter (1735-1808), Johann-Hieronymus Chemnitz (1730-1800) and Ignaz von Born (1742-1791) in Vien and a large number of studies was devoted to polyps, polyparies, starfishes, zoophytes, mollusks, testacea, entomostraca, etc. Everything that lived in the water was described, drawn and sometimes illuminated by many authors who often published in small journals with a poor circulation. In the south of Germany, following the example of Rösel and Schaeffer, a tradition of illuminated natural history developed that included many painter-naturalists as Georg-Wolfgang Knorr (1705-1761), Georg-Dionysius Ehret (c. 1708-1770), Johann-Christoph Heppe (1745-1806). The Linnaeans, for instance Eugen-Johann Esper (1742-1810) also used illuminated iconography to treat their subject, comprising zoophytes. In the north of Germany a new generation of scholars succeeded Klein as Joachim-Friedrich Bolten (17181796), Nicolaus-Georg Geve (1712-1789), Johann-Friedrich Herbst (1743-1807).

In Denmark, Müller, who was in touch with the scholarly societies of all Europe, was on his own one of the most fertile and diversified authors in the field of marine zoology. And in Sweden, the influence of Carl von Linnaeus (1707-1778), that progressively structured all natural history (Linnaeus, 1758), also reached marine zoology thanks to the studies developed by his disciples, Pehr Löfling (1729-1756) and Henric Fougt (1720-1782), as well as by naturalists and travellers such as Pehr Forsskål (1732-1763), who explored the marine fauna of Yemen.

\section{Conclusions}

Since the 1740s, the research on marine or microscopic organisms benefited from the new naturalized environment; it created new images and made visible unusual shapes that forced naturalists to look outside their traditional views of the animal kingdom. The growing circulation of those bodies and images across Europe 
created new challenges. At the theoretical viewpoint, one should think of both the diversity and the unity of nature, and, as Bonnet wrote: " the huge variety of the models on which organised bodies were built » (Di Pietro, 1984) should not hide the profound unity of life. Along that line, the wave of anonymous organisms arriving in Europe called for new methods of distribution. Fishes for instance, amounted to 230 in Artedi's in 1738 and were 20'000 in Cuvier and Achille Valenciennes (1794-1865) work in 1828. To overcome the difficulty, the methods of classification and nomenclature created by Linnaeus gave an overview of nature and a knowledge of details. The study of the physiological properties of organisms performed mainly by Trembley was complementary to the cult of the naturalist description established by Linnaeus and to a large extent novel. Since the French Revolution, Europe and then the world had become Linnaean, meanwhile the Marsili's jars and the Trembley's parcels, together with the Hydra now desacralized, definitely inaugurated a new face of science.

\section{Acknowledgements}

I am very grateful to Patricia Bossert and Brigitte Galliot for their dedicated work on the translation and adaptation of this text, which was originally published in French as a monography in the framework of the Exhibition entitled «Abraham Trembley et la naissance de la zoologie marine » organized in 2010 in Geneva to celebrate Abraham Trembley's 300 th birthday (www.ville-ge.ch/bge/actualites/exposition-2010-abraham-trembley.htm). I would also like to thank Thierry Dubois and the Bibliothèque de Genève for allowing me to use the figures of the original French monography "L'effet Trembley ou la naissance de la zoologie marine », Genève, La Baconnière Arts et Bibliothèque de Genève, 2010. All figures are copyright Bibliothèque de Genève, Geneva, except for Fig. 4A (left panel) which is copyright Institut de France, Académie des Sciences, Paris.

\section{References}

BAKER, H. (1742). The Microscope Made Easy. , R. Dodsley, London.

BAKER, H. (1743). An attempt towards a Natural History of the polype. R. Dodsley, London.

BAKER, J.R. (1952). Abraham Trembley of Geneva, Scientist and Philosopher (1710-1784). Arnold, London.

BERTRAND, J.-E. (1776). Description des Arts et Métiers. Imprimerie de la Société Typographique, Neuchâtel.

BOERHAAVE, H. (1725). Preface to Marsili, Histoire physique de la mer. Aus dépens de la Compagnie, Amsterdam, pp. III-V.

BOHADSCH, J.B. (1761). De quibusdam animalibus marinis, eorumque proprietatibus, orbi litterario vel nondum vel minus notis, liber. Georg Conrad Walther, Dresdae.

BONNATERRE, P.-J. (1788). Tableau encyclopédique et méthodique des trois règnes de la nature, Ichthyologie. Panckoucke, Paris.

BUSCAGLIA, M., DUBOULE, D. (2002). Developmental biology in Geneva: a three century-long tradition. Int J Dev Biol 46: 5-13

CAVOLINI, F. (1785). Memorie per servire alla storia de' polipi marini [s. n.], Napoli.

CRONE, G.R. (1966). Maps and their makers: an introduction to the history of cartography, 3rd ed. Hutchinson, London.

DAWSON, V. P. (1991). Regeneration, parthenogenesis, and the immutable order of nature. Archiv Nat. History 18: 309-321.

DI PIETRO, P. (1984). Letter from Bonnet to Spallanzani, 24 September 1774, in Carteggi di Lazzaro Spallanzani. Mucchi, Milano, p. 248.

DONATI, V. (1750). Storia naturale marina dell'Adriatico. Francesco Storti, Venezia.

DONATI, V. (1758). Essai sur l'histoire naturelle de la mer Adriatique. Pieter de Hondt, La Haye.

DINSMORE, C.E. (1996). Urodele limb and tail regeneration in early biological thought: an essay on scientific controversy and social change. Int J Dev Biol 40: 621-627.
DUHAMEL DU MONCEAU, H.-L., LA MARRE, L.H. (1769). Traité général des pesches: et histoire des poissons qu'elles fournissent tant pour la subsistance des hommes que pour plusieurs autres usages qui ont rapport aux arts et au commerce. Saillant et Nyon, Paris.

FRYER, G. (2008). Jacob Christian Schäffer FRS, a versatile eighteenth-century naturalist, and his remarkable pioneering researches on microscopic crustaceans. Notes and Records of the Royal Society 62: 167-185.

GALLIOT, B., SCHMID, V. (2002). Cnidarians as a model system for understanding evolution and regeneration. Int J Dev Biol 46: 39-48.

GIERER, A. (2012). The Hydra model - a model for what? Int J Dev Biol 56: 437-445.

GINANNI, G. (1741). Lettera intorno il prodigioso pascersi delle telline ed altre marine conchiglie. [Letter from Ginnani to the Bologna Academy of sciences, 15 March 1738]. Miscellanea di varie operette, V: 87-126, p. 100.

GOUAN, A. (1770). Histoire des poissons. Amand König, Strasbourg.

GRONOVIUS, J.-F. (1742). Concerning a Water Insect, which, being cut into several Pieces, becomes so many perfect Animals. Philos. Trans. 42: 218-220.

HEILBRON, J.L. (1966). A propos de l'invention de la bouteille de Leyde. Rev. d'Hist Sci. 19: 133-142.

HILL, J. (1752). Essays in Natural History and Philosophy. Containing a Series of Discoveries, by the Assistance of Microscopes. J. Whiston, London, pp. 20-22.

JUSSIEU, B.D. (1742a). Examen de quelques productions marines qui ont été mises au nombre des plantes, \& qui sont l'ouvrage d'une sorte d'insectes de mer. Mémoires de l'Académie royale des sciences de Paris: 290-302.

JUSSIEU, B.D. (1742b). Procès-verbaux de l'Académie. Archives of the Académie des sciences de Paris 61: 292, 424, 543.

LA CONDAMINE, C.-M.D. (1745). Relation abrégée d'un voyage fait dans l'intérieur de l'Amérique méridionale. Veuve Pissot, Paris.

LAZZARI, C. (2006). Quattro secoli di storia e ricerche naturalistiche nel territorio veneziano. Nuova dimensione, Venezia.

LINNAEUS, C. (1758). Systema Naturae per regna tria naturae, secundum classes, ordines, genera, species, Editio decima, reformata. Laurentii Salvii, Holmiae.

MALESHERBES, CHRÉTIEN-GUILLAUME DE. (1798). Observations sur l'histoire naturelle, générale et particulière de Buffon et Daubenton. Pougens, Paris, 2 vol. vol. 2: 184-185.

MARSILI, L.F., BOERHAAVE, H. (1725). Histoire physique de la mer. Ouvrage enrichi de figures dessinées d'après le naturel. Aus dépens de la Compagnie, Amsterdam.

MCCONNELL, A. (1990). The flowers of coral - Some unpublished conflicts from Montpellier and Paris during the early 18th century. Hist. Philos. Life Sci. 12:51-66.

NEEDHAM, J.T. (1747). Nouvelles découvertes faites avec le microscope. Elie Luzac fils, Leide.

PARSONS, J. (1752). Philosophical Observations on the Analogy between the Propagation of Animals and that of Vegetables. C. Davis, London.

PEYSSONEL, J.-A. (1756). Traduction d'un article des Transactions Philosophiques sur le Corail, London.

RATCLIFF, M.J. (2004). Abraham Trembley's strategy of generosity and the scope of celebrity in the mid-eighteenth century. Isis 95: 555-575.

RATCLIFF, M.J. (2006). Forms shaped by functions? Using, improving and conceiving microscopes during the 1740s, In Who Needs Instruments? (GROOB, B., MOOIJMAIJERS, H. Eds.). Museum Boerhaave, Leiden, pp. 235-244.

RÉAUMUR, R.-A.F.D. (1709). De la formation et de l'accroissement des coquilles des animaux tant terrestres qu'aquatiques. In Mémoires de l'Académie royale des sciences de Paris (LIBRAIRES, P.L.C.D., Ed.). Paris, pp. 364-400.

RÉAUMUR, R.-A.F.D. (1714). Sur les diverses reproductions qui se font dans les écrevisses, les omars, les crabes, etc. et entre autres sur celles de leurs jambes et de leurs écailles. Histoire de l'Académie royale des sciences de Paris :223-241.

RÉAUMUR, R.-A.F.D. (1734-1742). Mémoires pour servir à l'histoire des insectes. 6 volumes. Imprimerie royale, Paris.

RÖSEL VON ROSENHOF, A.J. (1755). Die Historie der Polypen der sussen Wasser und anderer kleiner Wasserinsecten hieriges Landes, Der Monatlich Herausgegeben Insecten Belustigung 3: 433-624.

SAINT-DENIS, E.D. (1955). Pline l'Ancien, Histoire naturelle. Belles Lettres, Paris.

SCHAEFFER, J.C. (1752). Apus Pisciformis, insecti aquatici species noviter detecta, breviter descripta. Impensis Jo. Mich. Seligmanni, Norimbergae. 
SCHAEFFER, J.C. (1754). Die Armpolypen in den süßen Wassern um Regensburg. Emanuel-Adam Wei $\beta$, Regensburg.

SCHAEFFER, J.C. (1755a). Die Blumenpolypen der süßen Wasser, beschrieben, und mit den Blumenpolypen der salzigen Wasser verglichen. Emanuel-Adam Wei $\beta$, Regensburg.

SCHAEFFER, J.C. (1755b). Die grünen Armpolypen, die geschwänzten und ungeschwänzten zackigen Wasserflöhe. Emanuel-Adam Wei $\beta$, Regensburg.

SCHUCHERT, P. (2008). The European athecate hydroids and their medusae (Hydrozoa, Cnidaria): Filifera Part 3. Rev Suisse Zool 115: 221-302.

TREMBLEY, A. (1745). Letter from Trembley to William Bentinck, 18 June 1745. British Library, Ms Egerton 1726, f. 6.
TREMBLEY, M., GUYÉNOT, É. (1943). Correspondance inédite entre Réaumur et Abraham Trembley. Georg, Genève.

VEDRENNE, I. (2002). L'homme sous la mer. La figure du plongeur dans le monde gréco-romain et l'Occident médiéval, in: JAMES-RAOUL, D., THOMASSET, C.A. (Eds.), Dans l'eau, sous l'eau: le monde aquatique au moyen âge. Presse de I'Université Paris-Sorbonne, Paris, pp. 273-319.

VIANELLI, G. (1749). Nuove scoperte intorno alla luce notturna dell'acqua marina F. Pitteri, Venezia.

WATSON, W. (1753). A treatise upon coral, and several other productions furnish'd by the sea, in order to illustrate the natural history thereof, by the Sieur de Peyssonnel. Philos. Trans. 47: 447-469.

\section{Further Related Reading, published previously in the Int. J. Dev. Biol.}

A polymorphic, thrombospondin domain-containing lectin is an oocyte marker in Hydractinia: implications for germ cell specification and sex determination

Brahim Mali, R. Cathriona Millane, Günter Plickert, Marcus Frohme and Uri Frank

Int. J. Dev. Biol. (2011) 55: 103-108

Reassessing the role of protein-carbohydrate complementarity during sperm-egg interactions in the mouse

Barry D. Shur

Int. J. Dev. Biol. (2008) 52: 703-715

The structure of sulfated polysaccharides ensures a carbohydrate-based mechanism for species recognition during sea urchin fertilization

Ana-Cristina E.S. Vilela-Silva, Noritaka Hirohashi and Paulo A.S. Mourão

Int. J. Dev. Biol. (2008) 52: 551-559

Metamorphosis of Hydractinia echinata (Cnidaria) is caspase-dependent Stefanie Seipp, Karola Wittig, Beate Stiening, Angelika Böttger and Thomas Leitz Int. J. Dev. Biol. (2006) 50: 63-70

Patterning a multi-headed mutant in Hydractinia: enhancement of head formation and its phenotypic normalization.

Werner A Müller, Regina Teo and Frank Möhrlen

Int. J. Dev. Biol. (2004) 48: 9-15

5 yr ISI Impact Factor $(2010)=2.961$

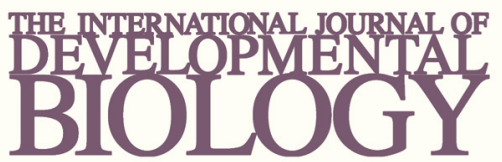

Volume 54 Nos. 6/7
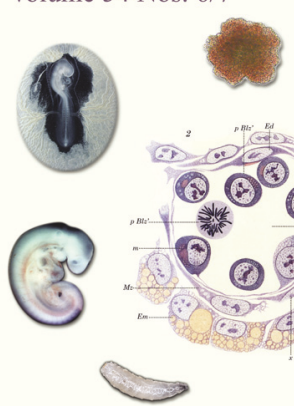

(2) (8) (8)
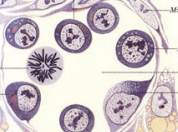

(1)
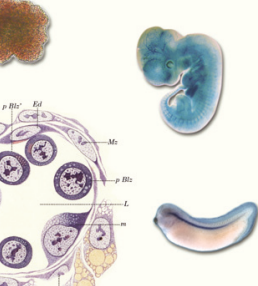

Developmental Hematopoiesis

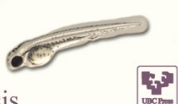

wacher

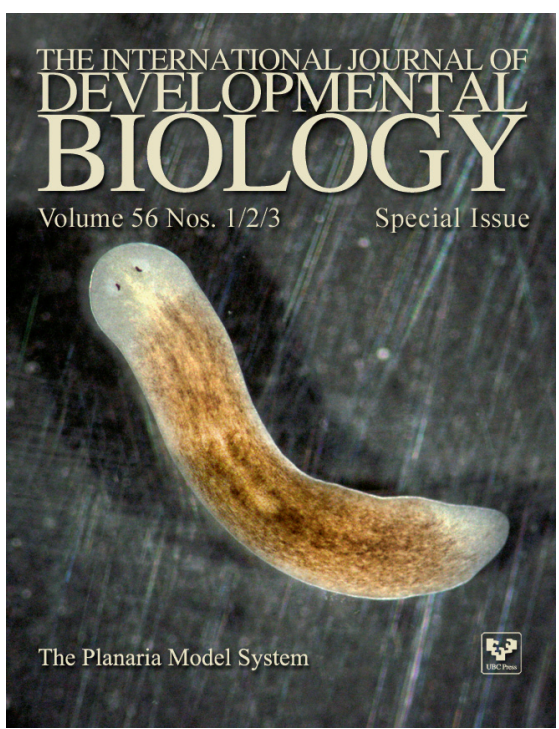

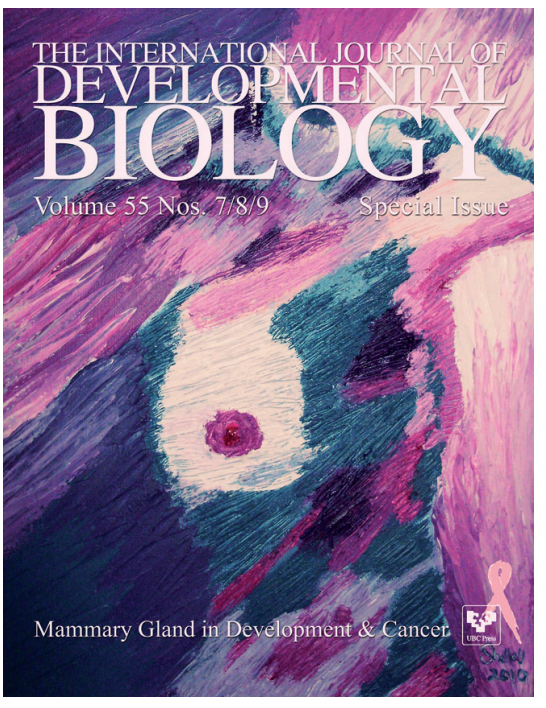

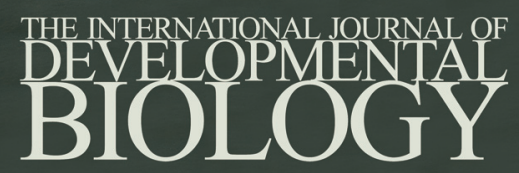

Volume 55 Nos. $4 / 5$

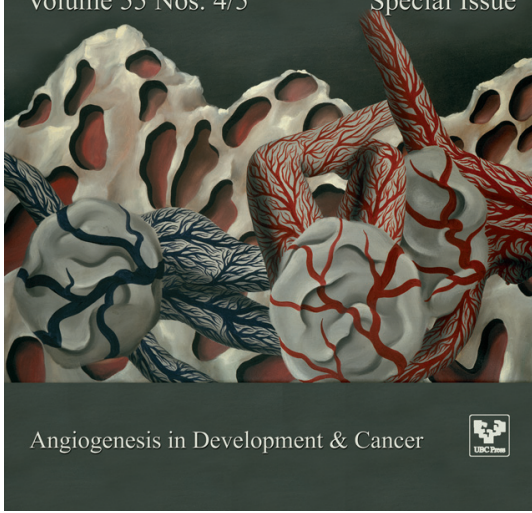

